\title{
The Role of Different Species of Bacteria in the Hydrolysis of Protein in the Rumen
}

\author{
By R. J. WALLACE* AND MARGARET L. BRAMMALL \\ Rowett Research Institute, Bucksburn, Aberdeen AB2 9SB, UK
}

(Received 9 August 1984; revised 7 November 1984)

\begin{abstract}
Proteolytic strains of Bacteroides amylophilus, Bacteroides ruminicola, Butyrivibrio fibrisolvens, Butyrivibrio alactacidigens, Selenomonas ruminantium var. ruminantium, Se. ruminantium var. lactilytica and of the genera Eubacterium, Fusobacterium and Clostridium were isolated from the rumen of sheep. The location of the proteolytic enzymes, their activity against various substrates and their sensitivity to inhibitors were compared with the same properties of mixed bacteria prepared from strained rumen fluid, in order to assess the relative importance of the different species in the hydrolysis of protein in the rumen. Bacteroides ruminicola was judged by these criteria to be the most important of these proteolytic isolates in vivo. Other isolates of higher specific activity had enzymes with properties different from rumen fluid. Species of Butyrivibrio, Selenomonas and Clostridium of lower specific activity may also be important if present in sufficiently large numbers, as their activity was of the same type as the mixed population.

Streptococcus bovis had a low proteolytic activity as determined by the conversion of ${ }^{14} \mathrm{C}$ labelled casein to TCA-soluble products, but was able to grow on casein, probably by virtue of its exceptionally high leucine aminopeptidase activity.
\end{abstract}

\section{INTRODUCTION}

A common problem in identifying the most important of a number of species of bacteria performing the same biochemical function in an ecosystem as complex as the rumen is to decide if bacterial numbers, specific activity or some other criterion is of greatest significance. With proteolysis in the rumen, a combination of high specific activity and large numbers has been taken to implicate Bacteroides amylophilus (Blackburn \& Hobson, 1962), Bacteroides ruminicola (Blackburn \& Hobson, 1962; Hazlewood \& Nugent, 1978), Streptococcus bovis and Butyrivibrio spp. (Fulghum \& Moore, 1963; Hazlewood et al., 1983) as the most important bacteria in the hydrolysis of protein in the rumen. The proliferation of Strep. bovis in casein-containing mixed cultures of rumen bacteria in vitro was similarly taken to suggest that it is an important proteolytic organism (Russell et al., 1981). In addition to these bacteria, proteolytic species of Selenomonas, Eubacterium, Succinivibrio, Lachnospira, Clostridium and Bacillus have been isolated (Blackburn \& Hobson, 1962; Fulghum \& Moore, 1963; Hungate, 1966), but their overall significance to the hydrolysis of protein in the rumen has never been established.

The aim of the present paper was to evaluate the likely importance of different proteolytic bacterial species in the rumen by their enzymological properties as well as by cell numbers and specific activity.

\section{METHODS}

Animals. Six mature sheep, each fitted with a rumen fistula, received food twice daily at an energy intake of approximately the maintenance level. Sheep A, B and C received a diet of two parts hay and one part dried grass, while sheep $D, E$, and $F$ received two parts hay and one part of barley-based concentrate.

Abbreviations: DANM, diazoacetylnorleucine methyl ester; GDH, glutamate dehydrogenase; NEM, $N$ ethylmaleimide; PCMB, $p$-chloromercuribenzoate; PMSF, phenylmethylsulphonyl fluoride; TLCK, $N$ - $\alpha$ - $p$-tosylL-lysine chloromethyl ketone; TPCK, L-1-tosylamide-2-phenylethylchloromethyl ketone. 
Culture media. Anaerobic techniques were used in the preparation of all culture media (Hungate, 1969). Three different media were used for the isolation of bacteria. Medium 1 was the non-selective, rumen fluid-containing medium described by Hobson (1969). Medium 2 contained the same minerals and sugars but no rumen fluid, $\left(\mathrm{NH}_{4}\right)_{2} \mathrm{SO}_{4}$, Bactocasitone or yeast extract; the only sources of nitrogen were cysteine, used to reduce the medium, and casein $\left(10 \mathrm{~g} \mathrm{t}^{-1}\right)$. Medium 3 was similar to medium 2 but contained maltose as the only sugar. These media

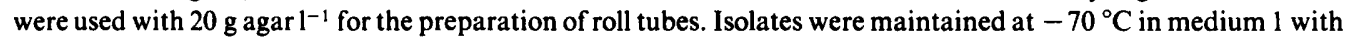
$20 \%(\mathrm{v} / \mathrm{v})$ glycerol added as a cryoprotective agent (Teather, 1982). The growth medium for the determination of fermentation products contained glucose, Bactocasitone, yeast extract, cysteine, minerals and resazurin as for medium 1, with added B-vitamins (Scott \& Dehority 1965), haemin and volatile fatty acids (except acetate; Varel et al., 1974). Cellulolytic activity was tested with cellulose roll-tubes or with filter paper strips (Stewart et al., 1981). Medium for the detection of spores contained per litre: $5 \mathrm{~g}$ cooked meat medium (Oxoid), $1 \mathrm{~g}$ cysteine hydrochloride, $0.2 \mathrm{~g}$ glucose and $20 \mathrm{~g}$ agar. The medium was boiled and $\mathrm{O}_{2}$-free $\mathrm{CO}_{2}$ was passed through the liquid before autoclaving. Slopes were inoculated from a liquid culture in medium 1 and incubated for $7 \mathrm{~d}$ before being examined microscopically for spores.

The basal medium for growth of isolates on media containing different nitrogen sources contained minerals, except $\left(\mathrm{NH}_{4}\right)_{2} \mathrm{SO}_{4}$, and resazurin as for medium 1, with added B-vitamins (Scott \& Dehority, 1965), volatile fatty acids (Caldwell \& Bryant, 1966), haemin $\left(0.001 \mathrm{~g}^{-1}\right)$, trace metals (Clark \& Holms, 1976), glucose $\left(2 \mathrm{~g} \mathrm{l}^{-1}\right)$ and dithiothreitol $\left(0.6 \mathrm{~g} \mathrm{l}^{-1}\right)$. Ammonium chloride $\left(0.535 \mathrm{~g} \mathrm{l}^{-1}\right)$ and vitamin-free Casamino acids (Difco; $2 \mathrm{~g} \mathrm{l}^{-1}$ ) were added, where appropriate, to the basal medium before autoclaving, and Casitone and proteins were added as filter-sterilized solutions after autoclaving to give a final concentration of $1 \mathrm{~g} \mathrm{l}^{-1}$. The inoculum was one drop (from a Pasteur pipette, approx. $30 \mu \mathrm{l}$ ) of a fresh culture grown on medium 1, and the optical density was read at 18 , 24,48 and $72 \mathrm{~h}$, as described below.

Isolation of proteolytic bacteria. Samples of rumen fluid were removed via the rumen fistulae, strained through four layers of muslin and serially diluted under $\mathrm{CO}_{2}$ in an anaerobic solution containing the mineral components of medium 1, with added Tween $80\left(1 \mathrm{~g} \mathrm{l}^{-1}\right)$ and cysteine hydrochloride $\left(1 \mathrm{~g}^{-1}\right)$. Portions $(0.5 \mathrm{ml})$ of dilutions $10^{-5}$ to $10^{-9}$ were used to form roll-tubes with isolation medium 1,2 or 3 . The roll-tubes were incubated at $39^{\circ} \mathrm{C}$ and inspected daily. Colonies were picked randomly from medium 1, but only colonies showing clearings or rings of casein precipitation were picked from media 2 and 3 . The colonies were inoculated into the corresponding liquid form of the isolation media, and the tubes were incubated at $39^{\circ} \mathrm{C}$. When growth was observed, these cultures were used to inoculate one tube containing $5 \mathrm{ml}$ of liquid medium 1 and another containing $5 \mathrm{ml}$ of medium 2 . When these cultures had reached stationary phase (usually after $24 \mathrm{~h}$, but at later times for some cultures), they were harvested $\left(15000 \mathrm{~g}, 15 \mathrm{~min}, 4^{\circ} \mathrm{C}\right)$, resuspended in $50 \mathrm{~mm}$-potassium phosphate buffer, $\mathrm{pH} 7.5$, and incubated with an equal volume of azocasein $\left(2 \mathrm{~g} \mathrm{l}^{-1}\right)$ at $39^{\circ} \mathrm{C}$ for $24 \mathrm{~h}$. The extent of azocasein digestion was estimated as described previously (Kopecny \& Wallace, 1982).

Identification of isolates. Bacteria were identified by the criteria described by Buchanan \& Gibbons (1974), Holdeman et al. (1977) and Starr et al. (1981) and using the methods described by Holdeman et al. (1977) unless otherwise stated. Cell wall ultrastructure was determined by transmission electron microscopy (Wallace $e t$ al., 1979).

The fermentation of sugars was determined using medium 1 from which all sugars and lactate had been omitted except the one being tested. A positive reaction was recorded when the $\mathrm{pH}$ of the medium had fallen by more than 0.2 units compared with sugar-free medium after incubation at $39^{\circ} \mathrm{C}$ for $7 \mathrm{~d}$.

Fermentation products from glucose were determined by GLC for volatile fatty acids (Fell et al., 1968), by microdiffusion for total lactate (Conway, 1957), and enzymically for ethanol (Bernt \& Gutmann, 1974), succinate (Clark \& Porteous, 1964), L-lactate (Wallace, 1978) and formate. The formate assay ( $\mathrm{pH} 7 \cdot 0$ ) contained $0 \cdot 16 \mathrm{M}-$ potassium phosphate, $0.4 \mathrm{mM}-\mathrm{NAD}^{+}$and $80 \mu \mathrm{g}$ formate dehydrogenase $\mathrm{ml}^{-1}$. Formate dehydrogenase (EC 1.2.1.2; $0.6 \mathrm{U} \mathrm{mg}^{-1}$ ) was obtained from Boehringer. A sample containing up to $0.25 \mu \mathrm{mol}$ formate was added to $1 \mathrm{ml}$ of this mixture and incubated at $39^{\circ} \mathrm{C}$ for $2 \mathrm{~h}$. The absorbance of NADH was measured at $340 \mathrm{~nm}$. At this time the reaction was incomplete, but the formate concentration could be determined from a (non-linear) calibration graph. Acetate was sometimes measured by an enzymic method (Holz \& Bergmeyer, 1974).

Measurement of proteolytic activity. The proteolytic activity of $24 \mathrm{~h}$ cultures of isolates was determined with casein and other proteins labelled with ${ }^{14} \mathrm{C}$ by reductive methylation (Wallace, 1983). The assay mixture contained per $\mathrm{ml}$ final volume at $\mathrm{pH} 7 \cdot 5$ : potassium phosphate, $25 \mu \mathrm{mol} ;{ }^{14} \mathrm{C}$-labelled protein [specific radioactivity about $0.4 \mathrm{MBq}$ (g protein) ${ }^{-1}$ ], $2 \mathrm{mg}$; and ethanol, $50 \mathrm{mg}$. This mixture was incubated for $24 \mathrm{~h}$ at $39^{\circ} \mathrm{C}$, and the extent of digestion of protein was estimated by adding TCA to a final concentration of $5 \%(w / v)$, centrifuging $(12000 \mathrm{~g}, 3 \mathrm{~min})$, and counting $0.2 \mathrm{ml}$ of the supernatant fluid by liquid scintillation spectrometry. The quantity of culture added depended on its proteolytic activity. A volume was chosen so that no more than $40 \%$ of the substrate was converted to TCA-soluble products during the incubation, the extent of digestion usually being much less than this value. The proteolytic activities of a bacterial fraction from rumen fluid (Kopecny \& Wallace, 1982) and of isolate M3713 were measured using the same procedure, except that azocasein replaced $\left[{ }^{14} \mathrm{C}\right]$ casein in the assay 
mixture and the extent of digestion was determined by mixing the TCA-soluble material with an equal volume of $0.5 \mathrm{M}-\mathrm{NaOH}$ and measuring the absorbance of this solution at $440 \mathrm{~nm}$.

Measurement of amino acyl amidases. The specificities of peptidase activity of rumen fluid and of the proteolytic isolates were assessed using $p$-nitroanilides of some free and substituted amino acids. Fresh cultures of isolates grown in medium 1 were centrifuged $\left(27200 \mathrm{~g}, 15 \mathrm{~min}, 4^{\circ} \mathrm{C}\right)$ and resuspended in $25 \mathrm{~mm}$-potassium phosphate, pH 7.5. The bacterial fraction from rumen fluid was centrifuged and resuspended in the same way. These bacterial suspensions were then incubated at $39^{\circ} \mathrm{C}$ in an assay mixture $(\mathrm{pH} \mathrm{7.5)}$ which contained per ml: bacterial suspension, $0.3 \mathrm{ml}$; potassium phosphate, $25 \mu \mathrm{mol}$; $p$-nitroanilide substrate, $0.5 \mu \mathrm{mol}$; and ethanol, $50 \mathrm{mg}$. The reaction was terminated after $6 \mathrm{~h}$ and $24 \mathrm{~h}$ by adding TCA to a final concentration of $5 \%(\mathrm{w} / \mathrm{v})$, and this mixture was centrifuged $(12000 \mathrm{~g}, 3 \mathrm{~min})$. The concentration of $p$-nitroaniline in the supernatant fluid was determined by diazotization (Appel, 1974). p-Nitroaniline $(50 \mu \mathrm{M})$ was incubated with each of the bacterial suspensions in order to measure how much of the product was further metabolized, and this was compensated for in subsequent calculations.

Bacterial cell density. The cell density of bacterial suspensions was calculated from their optical densities at $640 \mathrm{~nm}$ in a Cecil CE595 double beam spectrophotometer (Cecil Instruments, Cambridge, UK). Suspensions were diluted to give a reading of $<0.5$. It was assumed here that the relationship between dry weight concentration and optical density was the same in different species, as was found previously with rumen bacteria of different morphologies (Marounek \& Wallace, 1984).

Cell fractionation. Proteolytic isolates were grown overnight at $39^{\circ} \mathrm{C}$ and then centrifuged $(27200 \mathrm{~g}, 15 \mathrm{~min}$, $\left.4{ }^{\circ} \mathrm{C}\right)$. The proteolytic activity of the supernatant fluid was determined using $\left[{ }^{14} \mathrm{C}\right]$ casein as described above. The pellet was resuspended in $50 \mathrm{~mm}$-potassium phosphate, $\mathrm{pH} 7.5$, and its proteolytic activity was determined directly, after blending in a Waring blender, and after blending followed by sonication (Kopecny \& Wallace, 1982). Cell lysis was assessed by measuring the NAD-linked glutamate dehydrogenase (EC 1.4.1.2) activity of the different fractions (Wallace, 1979).

\section{RESULTS}

A total of 81 cultures was screened for azocasein digestion from samples taken from sheep receiving the hay + dried grass diet, of which 48 were proteolytic and able to be maintained in medium 1 . Of the 44 cultures obtained from sheep fed hay + concentrate, 22 were proteolytic and could be maintained in medium 1 . The number of isolates identified in this study was too small to determine if there was a different type of proteolytic population in animals receiving different diets, but no difference was apparent in the morphological characteristics of the total number of organisms which were isolated (which were mostly not identified). Furthermore, the growth media which were intended to be selective for growth of proteolytic bacteria, insofar as casein and cysteine (the reducing agent) were the sole nitrogen sources in the medium, were no more successful for the selection of proteolytic bacteria than the general purpose medium 1 containing rumen fluid. Of a total of 65 colonies taken from the selective media 33 were proteolytic by the azocasein assay when grown in one of medium 1 or medium 2, whereas 37 of the 60 colonies picked off roll-tubes containing medium 1 were proteolytic.

Isolate M3713 was lost during the course of this work, so the results for this organism are incomplete. Some other strains, not selected for detailed study, also failed to maintain viability after a time. Other than the loss of organisms like strain M3713, which was a small and apparently fragile Gram-negative coccal rod, there was no obvious pattern in the type of isolate lost.

\section{Identification of proteolytic rumen bacteria}

A total of 15 proteolytic isolates was selected for further investigation on the basis of their morphology and fermentation products, so that representatives of different species would be studied. Full details of their characteristics are not given here. In general, only features of particular note or those which differ significantly from those recorded for other strains are described.

Bacteroides amylophilus M3713 was identified from only a few tests, but these were sufficiently unambiguous to be certain of this classification. The other Bacteroides strains, M279 and M384, clearly belonged to the species ruminicola, and both were assigned to ssp. ruminicola as the addition of haemin to defined medium was necessary for optimal growth. 
The Gram-negative butyrate-producing organisms selected included two strains (JW11 and SH1) similar to the type 1 Butyrivibrio fibrisolvens of Shane et al. (1969), except that they were not cellulolytic, being unable to hydrolyse either filter paper strips or cellulose powder. They also were positive for aesculin hydrolysis, unlike most other members of the species. Their cell envelope ultrastructure was of the typical thin Gram-positive type of Bu. fibrisolvens (Cheng \& Costerton, 1977). In contrast, strain $\mathrm{C} 3617$ had a normal Gram-negative envelope ultrastructure despite being closely similar to the organism named Butyrivibrio alactacidigens by Hungate (1966). Clearly this isolate is likely to be distantly related to $\mathrm{Bu}$. fibrisolvens.

Two clostridia were included in the survey. Strain M361 did not produce butyrate and was similar to $C$. clostridiiforme. Strain JW1 had a Gram-positive cell envelope and did not produce visible spores, although it survived heating at $80^{\circ} \mathrm{C}$ for $10 \mathrm{~min}$. As it was a strict anaerobe, it was classified as a Clostridium. Its sugar fermentation pattern was similar to strain M361, but butyrate, acetate and formate were its main products.

Eubacterium isolate M1710 was non-cellulolytic and produced butyrate and acetate as the main fermentation products from glucose. In many respects it resembled $E$. combesii. Strain JW7 was a Fusobacterium that differed from other fusobacteria in its wide range of sugars fermented, which included arabinose, cellobiose, aesculin, fructose, galactose, glucose, lactose, maltose, mannose, melibiose, rhamnose, ribose, salicin, sorbitol, sucrose and trehalose. Starch and xylose were not fermented.

The remaining strains were very similar to type strains of Selenomonas ruminantium var. ruminantium (strain JW2) and var. lactilytica (JW13), and Streptococcus bovis (C277, C351, M363).

\section{Growth of proteolytic rumen bacteria in media containing different sources of nitrogen}

Most isolates grew well with $\mathrm{NH}_{4}^{+}$as the sole source of nitrogen, and in media containing amino acids and casitone (Table 1). The only exceptions were Ba. ruminicola M279 and Fusobacterium sp. JW7, which grew less well on media containing $\mathrm{NH}_{4}^{+}$or amino acids than when casitone was the nitrogen source. No growth was obtained with Bu. alactacidigens $\mathrm{C} 3617$ or Eubacterium sp. M1710 on any of these media.

The amount of bacterial growth in media containing proteins was more difficult to quantify due to the precipitation of partly-digested protein which occurred with many cultures, and the results (Table 1) were taken from cultures at times when precipitation was judged to be absent or minimal. The results should therefore be taken as only indicative of the extent of growth. Nevertheless, the growth of the isolates in these media corresponded well with their proteolytic activity (Table 1). Those cultures with a proteolytic activity of $>0.6 \mathrm{mg}\left[{ }^{14} \mathrm{C}\right]$ casein hydrolysed (mg dry $w t)^{-1} d^{-1}$ grew on casein at a similar rate and to a similar cell density as they did on amino acids; those with activities of $0.2 \mathrm{mg}\left[{ }^{14} \mathrm{C}\right]$ casein hydrolysed (mg dry wt) ${ }^{-1} \mathrm{~d}^{-1}$ or less failed to grow appreciably on casein; and those with intermediate activities grew but more slowly and to a lesser extent than with amino acids. The isolates all grew less well on lactoglobulin, and especially on albumin and $\gamma$-globulins.

The proteolytic activity of several of the isolates was sometimes variable between different experiments separated by some months, for reasons which were not clear. However, there was no indication within experiments that the proteolytic activity of any of the isolates was markedly altered by the presence of any of $\mathrm{NH}_{4}^{+}$, amino acids or peptides in the medium, and it was concluded that the proteases of all of the species were synthesized constitutively.

Ba. amylophilus M3713 was lost before the experiments described in Table 1 were done. However, preliminary experiments had shown that $\mathrm{NH}_{4} \mathrm{Cl}$ as sole source of nitrogen did not support growth and that the peptides present in casitone were not essential for growth. The proteolytic activity of strain M3713 was determined with cultures grown on medium 1 using azocasein, and a specific activity of $0.37 \mathrm{mg}$ azocasein hydrolysed (mg dry wt) $)^{-1} \mathrm{~d}^{-1}$ was obtained for harvested, resuspended cells. Supernatant activity was not determined. The same batch of azocasein gave a specific activity of $0.07 \mathrm{mg}$ azocasein hydrolysed (mg dry wt) $)^{-1} \mathrm{~d}^{-1}$ for Ba. ruminicola $\mathrm{M} 384$, compared with $0.74 \mathrm{mg}\left[{ }^{14} \mathrm{C}\right]$ casein hydrolysed (mg dry wt) ${ }^{-1} \mathrm{~d}^{-1}$ from the sum of the cell-bound and extracellular activities (Table 4), so it can be estimated that the 


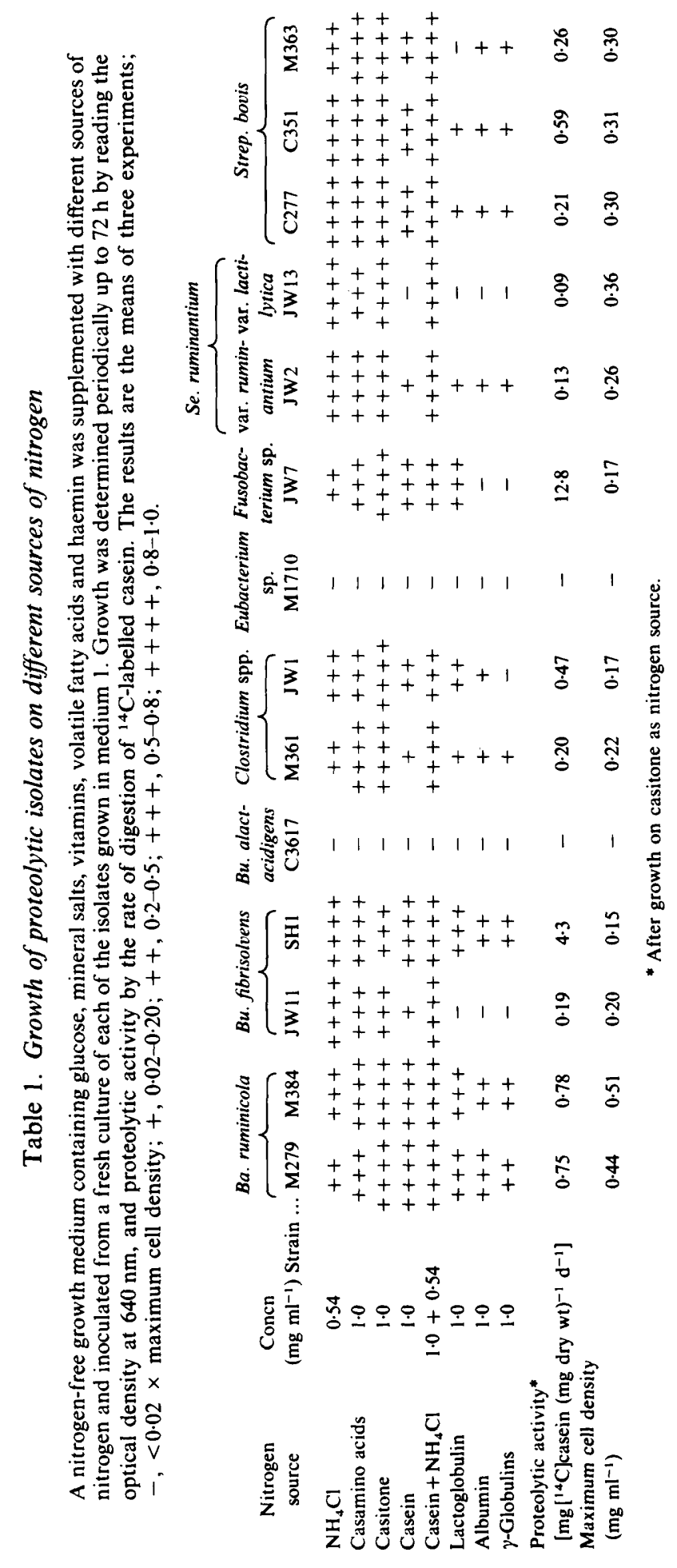


activity of Ba. amylophilus $\mathrm{M} 3713$ with $\left[{ }^{14} \mathrm{C}\right]$ casein as substrate would be about 10 -fold higher, at about $4 \mathrm{mg}\left[{ }^{14} \mathrm{C}\right]$ casein hydrolysed (mg dry $\left.\mathrm{wt}\right)^{-1} \mathrm{~d}^{-1}$. Again no induction or repression of activity was observed with cultures grown on different media.

\section{Protease activities with different substrates}

All of the bacteria hydrolysed lactoglobulin and haemoglobin as well as casein, although usually at a somewhat slower rate, but none was capable of rapid hydrolysis of either albumin or $\gamma$-globulins (Table 2). Indeed the relative rate of hydrolysis of albumin and $\gamma$-globulins was even slower than with mixed rumen bacteria. Two of the strains with the lowest protease activity, $B u$. fibrisolvens JW11 and Clostridium sp. M361, broke down $\beta$-lactoglobulin and haemoglobin more quickly than casein. In general, however, the pattern of susceptibility of the different proteins to hydrolysis by the isolates was quite similar to that for mixed rumen bacteria.

Amino acyl amidase activities of mixed rumen bacteria and of the isolates were measured with five amino acyl $p$-nitroanilides. Leucine $p$-nitroanilide and benzoyl arginine $p$-nitroanilide were readily hydrolysed by mixed rumen bacteria, and the former substrate was rapidly broken down by the isolates of Strep. bovis as well as more slowly by most of the other strains (Table 2). In contrast, benzoyl arginine $p$-nitroanilide, a substrate for trypsin-like enzymes, was resistant to hydrolysis by all of the isolates. The chymotrypsin substrates benzoyl tyrosine $p$-nitroanilide and $N$-acetyl phenylalanine $p$-nitroanilide were weakly hydrolysed by mixed rumen bacteria at rates of (mean $\pm \mathrm{SD}$ ) $0.014 \pm 0.007$ and $0.014 \pm 0.005 \mu \mathrm{mol}(\mathrm{mg} \text { dry wt) })^{-1} \mathrm{~d}^{-1}$, and not at all by any of the isolates. $N$-Acetyl alanine $p$-nitroanilide was not hydrolysed by mixed rumen bacteria or any of the isolates.

\section{Inhibition of proteolytic activities}

The susceptibilities of mixed rumen bacteria and of the proteolytic isolates to various inhibitors were compared (Table 3). Mixed rumen bacteria from sheep receiving both diets had a proteolytic activity which was strongly inhibited by the sulphydryl reagent $p$-chloromercuribenzoate (PCMB) and less so by another sulphydryl reagent, $N$-ethylmaleimide (NEM). Dithiothreitol (DTT) inhibited the activity to an extent similar to NEM, again indicating the involvement of cysteine residues in the catalytic mechanism. The serine protease inhibitor phenylmethylsulphonyl fluoride (PMSF) was also inhibitory, as was EDTA, which inhibits enzymes dependent on a metal ion for activity. The strongly inhibitory effect of $\mathrm{CuSO}_{4}$ on proteolysis was therefore probably due to its combined effects on thiol- and metal-dependent activity. Substrate analogues for particular specificities of proteolytic enzyme, including diazoacetylnorleucine methyl ester (DANM), $N$ - $\alpha$-p-tosyl-L-lysine chloromethyl ketone (TLCK) and L-1-tosylamide-2-phenylethylchloromethyl ketone (TPCK), which inhibit enzymes with specificities similar to pepsin, trypsin and chymotrypsin respectively (North, 1982), had little effect on the proteolytic activity of mixed rumen bacteria.

Among the proteolytic isolates, both Ba. ruminicola strains had a profile most similar to that of mixed rumen bacteria. Also quite similar were the Se. ruminantium isolates, which differed from mixed rumen bacteria mainly in a greater sensitivity to EDTA, TLCK and TPCK, and $B u$. fibrisolvens JW11, which was about $30 \%$ inhibited by TLCK and TPCK. Clostridium sp. JW1 was also quite similar, except that its activity was less sensitive to PCMB than mixed rumen bacteria. In contrast, the other isolate identified as $\mathrm{Bu}$. fibrisolvens (SH1) had a completely different profile. In common with Ba. amylophilus M3713, Bu. alactacidigens C3617, Fusobacterium sp. JW7, Eubacterium sp. M1710 and the Strep. bovis isolates, strain SH1 had activity mainly of the serine protease type, which is inhibited by PMSF and may or may not be inhibited by PCMB.

These results for the most part refer to cell-associated proteolytic activities. The sensitivity of extracellular enzymes to inhibitors was determined with only two of the isolates, Bu. fibrisolvens SH1 and Fusobacterium sp. JW7 (Table 3). The sensitivity of the extracellular enzyme(s) was in both instances similar to that of the cell-associated enzymes. 


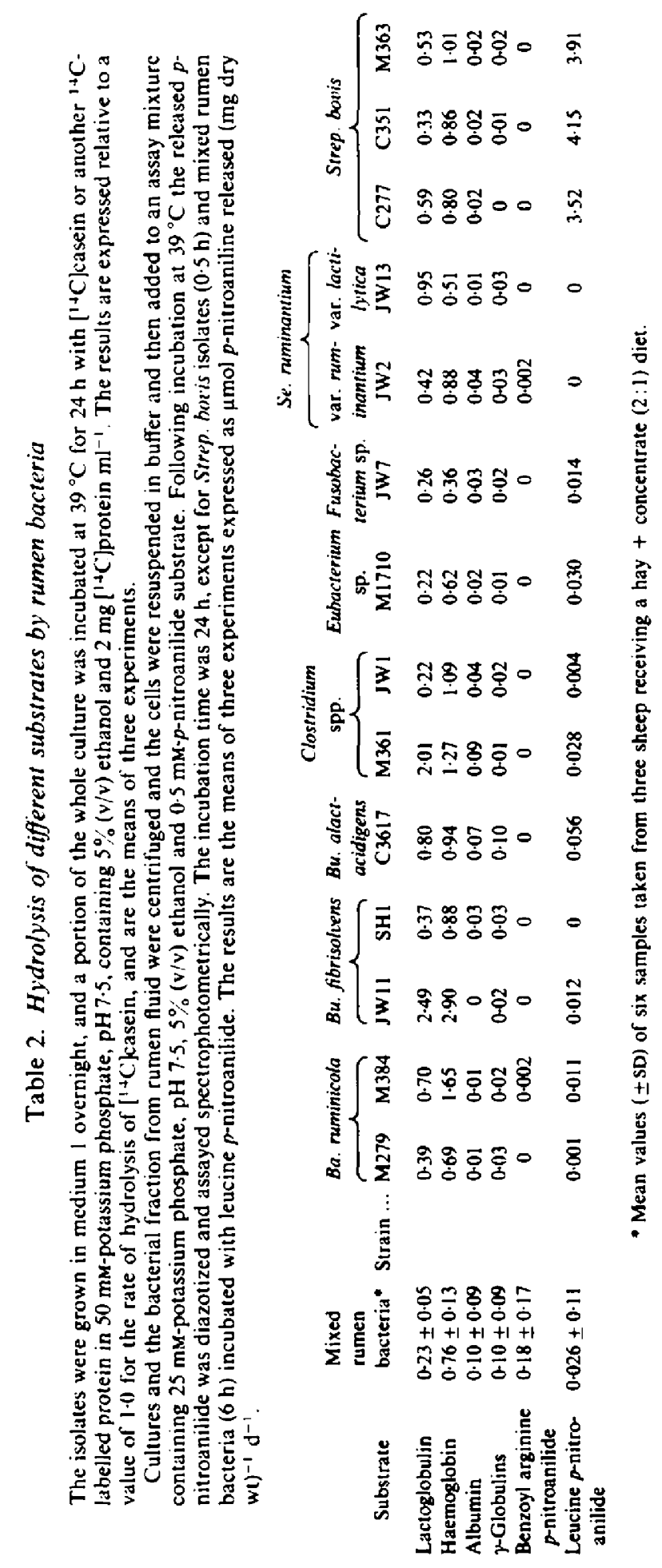




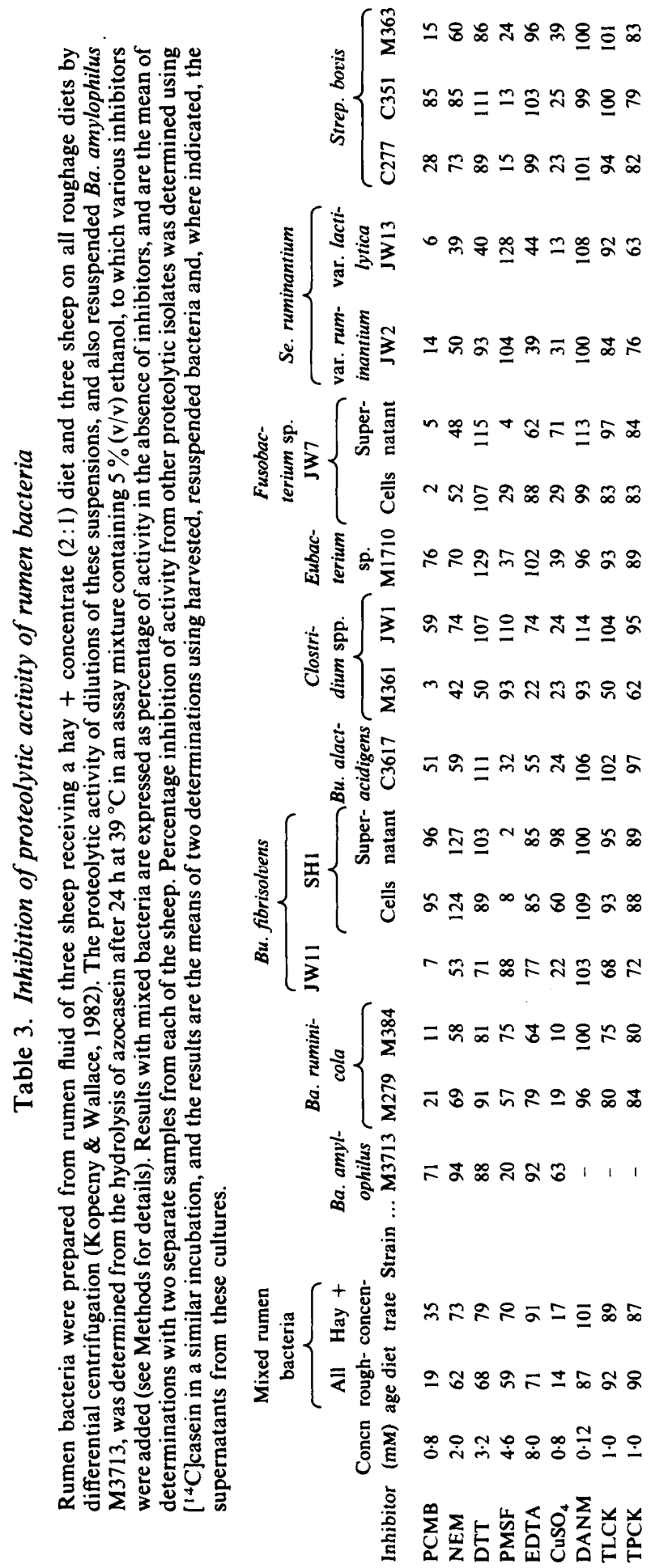




\section{Location of proteolytic enzymes}

A fractionation of the proteolytic isolates was done to compare the cellular distribution of proteolytic activity within the isolates (Table 4) with that found in mixed rumen bacteria (Kopecny \& Wallace, 1982). Cellular and extracellular activities were separated by centrifugation of fresh cultures. The distribution varied from mostly extracellular in $B u$. fibrisolvens $\mathrm{SH} 1$ and $\mathrm{Bu}$. alactacidigens $\mathrm{C} 3617$ to mainly cell-associated with Eubacterium sp. M1710 and the three Strep. bovis isolates. Blending, which has been used to remove capsular material from Aerobacter aerogenes (Yuruwitz et al., 1971), and which removes proteases from mixed rumen bacteria (Kopecny \& Wallace, 1982), solubilized different proportions of cellassociated activity from different species. The isolate with the highest cell-associated activity, Fusobacterium sp. JW7, released only a small proportion of its activity during blending, whereas many of the others, notably Ba. ruminicola M279, Bu. fibrisolvens JW11, Bu. alactacidigens $\mathrm{C} 3617$, Clostridium sp. JW1 and Se. ruminantium JW2, released activity equivalent to most of the measured cell-associated activity. Glutamate dehydrogenase (GDH) activity was used as an indicator of the contamination with cytoplasmic material of the extracts from blending (Table 4). Only Se. ruminantium JW2, the largest of the organisms isolated, released much GDH during blending. The other strains released a small proportion of their total GDH activity, indicating that while blending solubilized a significant proportion of their cell-associated proteases, this was not due to the release of intracellular enzymes. It should be noted that sonication of Strep. bovis is known to be inefficient in disrupting the cells, so the activities of GDH in sonicated extracts should be taken only as a guide to the location of proteolytic enzymes, and not as the total intracellular GDH or protease activity. This may apply as well to other strains.

\section{DISCUSSION}

Most of the proteolytic activity of rumen fluid is associated with bacteria, whether free-living or attached to plant fibres (Blackburn \& Hobson, 1960; Kopecny \& Wallace, 1982; Brock et al., 1982). This activity occurred in about half of the bacteria isolated from strained rumen fluid by Fulghum \& Moore (1963) and in a range of species. Furthermore, it was confirmed that selective media containing casein are not particularly efficient in selecting proteolytic organisms (Blackburn \& Hobson, 1962). A number of proteolytic isolates, including the Strep. bovis strains and Eubacterium sp. M1710 failed to clear casein-containing agar, presumably because most of the activity was cell-bound (Table 4) and did not diffuse through the medium.

The most active proteolytic isolates were $B a$. amylophilus, $B u$. fibrisolvens SH1, Bu. alactacidigens, and Fusobacterium sp. JW7 (Tables 1 and 4). Since all of the strains were isolated from $10^{-6}$ to $10^{-8}$ dilutions of strained rumen fluid, it might be expected that these were therefore potentially the most important proteolytic bacteria of the rumen. However, their activities were of the serine protease type, inhibited by PMSF (Table 3), unlike the mainly cysteine protease activity of the mixed population (Table 3; Kopecny \& Wallace, 1982). Moreover, with the exception of the fusobacterium, their activity was predominantly exocellular (Table 4) in contrast to the largely cell-bound activity of mixed rumen bacteria (Kopecny \& Wallace, 1982). Ba. amylophilus $\mathrm{H} 18$ similarly had mainly serine protease activity (Blackburn, 1968b) of a type different to that of mixed rumen bacteria.

Organisms with lower specific activities, but of the cysteine protease type, are probably of greater importance in the rumen. These include Ba. ruminicola, whose activity had a sensitivity to inhibitors that was similar in all respects to that of mixed rumen bacteria (Table 3) and which was partly cell-associated and was similarly partially released, without cell lysis, by disruption in a Waring blender (Table 4). The properties of strains M279 and M384 were fairly similar to those of Ba. ruminicola R8/4 (Hazlewood \& Edwards, 1981; Hazlewood et al., 1981). Strains of $B u$. fibrisolvens similar to strain JW11 could also be of major significance, as could Se. ruminantium, in view of the similarity of their activities to that of mixed rumen bacteria (Tables 3 and 4). Clearly these organisms, with their lower specific activity, would have to comprise a fairly large proportion of the population to be of quantitative significance, and their contribution to proteolysis will therefore depend to a large degree on the influence of diet on their numbers. 


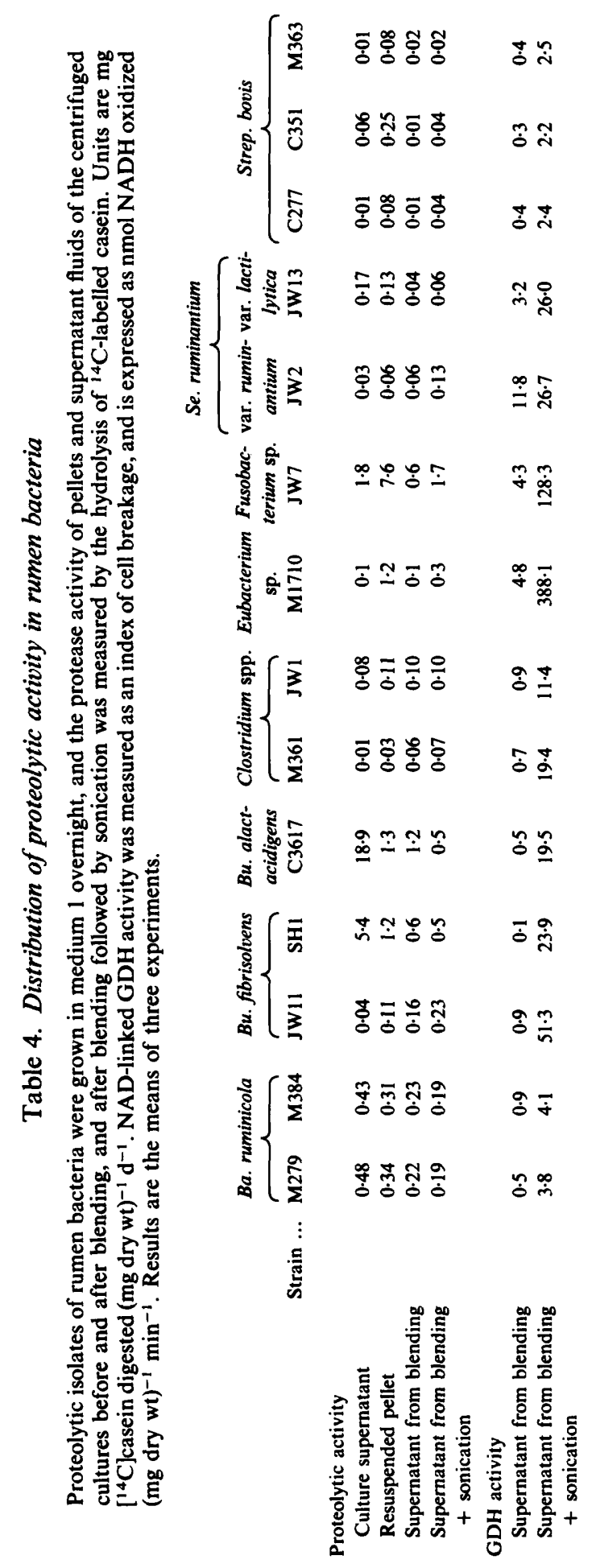


The location of the cell-bound proteolytic enzymes in these isolates is of interest, as less activity was removed from the isolates by blending (Table 4) than is removed by the same treatment of the mixed population (Kopecny \& Wallace, 1982). This may reflect the lesser quantities of capsular material produced in vitro by rumen bacteria. It was noted from electron micrographs that Ba. ruminicola M279 had surface 'blebs' similar to those found with $B a$. succinogenes and implicated in cellulase activity in the latter organism (Groleau \& Forsberg, 1981). It is tempting to speculate about their parallel role in proteolysis in $\mathrm{Ba}$. ruminicola.

Strep. bovis has been isolated in previous studies of proteolytic rumen bacteria (Blackburn \& Hobson, 1960, 1962; Hazlewood et al., 1983) and was the predominant proteolytic organism enriched for in continuous cultures with a rumen fluid inoculum (Russell et al., 1981). In the present paper, Strep. bovis had a fairly low activity, which nevertheless enabled growth on casein (Table 1). Its most unusual characteristic was, however, its very high leucine aminopeptidase activity (Table 2). Thus Strep. bovis probably participates very actively in exopeptidase activity in the rumen.

Despite the high activity of mixed rumen bacteria with the synthetic trypsin substrate benzoyl arginine $p$-nitroanilide, none of the isolates studied in detail had significant activity against this substrate (Table 2). Screening of the other bacteria isolated in this study also failed to identify an organism with a major activity of this type. It may therefore be necessary to use alternative isolation methods to search for organisms with this important peptidase activity.

Two general findings with all of the isolates have broader implications for the study of proteolysis in the mixed population in vivo. Firstly, proteolytic activity appears to be expressed constitutively as was found with Ba. amylophilus (Blackburn, 1968a). Thus differences in proteolytic activity caused by different diets (Siddons \& Paradine, 1981) are not likely to be due to changes in the induction/repression of enzyme activity, but to differences in size and composition of the microbial population. It may therefore be impossible to control proteolysis by affecting enzyme expression. Secondly, the relative rate of hydrolysis of different proteins depends much more on the identity of the protein substrate than on the activity of the organism (Table 2). Thus albumin and $\gamma$-globulins, which resist hydrolysis in the rumen (Wallace, 1983), are also refractory to breakdown by individual species. Attempts to manipulate proteolytic activity should therefore perhaps concentrate on the substrate rather than the microbial flora.

It should be emphasized that the work presented here, and the conclusions drawn from these studies, refer to the free-swimming bacteria in rumen liquor, since rumen contents were strained before use; $75 \%$ of the total biomass in the rumen is, however, associated with particulate material (Forsberg \& Lam, 1977). The conclusion that Ba. ruminicola and Strep. bovis are the most important proteolytic bacteria in the liquid phase of the rumen may therefore not also apply to the particle-bound bacteria and a separate study may be necessary to establish the organisms of corresponding importance in this adherent population.

The authors wish to thank Dr P. N. Hobson and Mrs S. Duncan for their help with identifications, Dr T. P. King for electron microscopy and Mrs S. Black and Miss S. Hatty for technical assistance.

\section{REFERENCES}

APPEL, W. (1974). Peptidases. In Methods of Enzymatic Analysis, 2nd edn, vol. 2, pp. 949-978. Edited by H. U. Bergmeyer. London: Academic Press.

BERNT, E. \& GUTMANN, I. (1974). Ethanol determination with alcohol dehydrogenase and NAD. In Methods of Enzymatic Analysis, 2nd edn, vol. 3, pp. 1499-1502. Edited by H. U. Bergmeyer. London: Academic Press.

BlackburN, T. H. (1968a). Protease production by Bacteroides amylophilus strain $\mathrm{H} 18$. Journal of General Microbiology 53, 27-36.

BlackbuRN, T. H. (1968b). The protease liberated from Bacteroides amylophilus strain $\mathrm{H} 18$ by mechanical disintegration. Journal of General Microbiology 53, 37-51.
Blackburn, T. H. \& Hobson, P. N. (1960). Proteolysis in the sheep rumen by whole and fractionated rumen contents. Journal of General Microbiology 22, 272281.

Blackburn, T. H. \& Hobson, P. N. (1962). Further studies on the isolation of proteolytic bacteria from the sheep rumen. Journal of General Microbiology 29, 69-81.

Brock, F. M., Forsberg, C. W. \& Buchanan-Smith, J. G. (1982). Proteolytic activity of rumen microorganisms and effects of proteinase inhibitors. Applied and Environmental Microbiology 44, 561-569.

Buchanan, R. E. \& Gibbons, N. E. (eds). (1974). Bergey's Manual of Determinative Bacteriology, 8th edn. Baltimore: Williams \& Wilkins. 
Caldwell, D. R. \& Bryant, M. P. (1966). Medium without rumen fluid for nonselective enumeration and isolation of rumen bacteria. Applied Microbiology 14, 794-801.

Cheng, K.-J. \& Costerton, J. W. (1977). Ultrastructure of Butyrivibrio fibrisolvens: a Gram-positive bacterium? Journal of Bacteriology 129, 1506-1512.

ClaRK, B. \& Holms, W. H. (1976). Control of the sequential utilization of glucose and fructose by Escherichia coli. Journal of General Microbiology 95, 191-201.

Clark, B. \& Porteous, J. W. (1964). Determination of succinic acid by an enzymic method. Biochemical Journal 93, 2 Ic.

Conway, E. J. (1957). Microdiffusion Analysis and Volumetric Error, 4th edn, pp. 277-278. London: Crosby Lockwood \& Son.

Fell, B. F., Kay, M., Whitelaw, F. G. \& Boyne, R. (1968). Observations on the development of ruminal lesions in calves fed on barley. Research in Veterinary Science 9, 458-466

ForsberG, C. W. \& LAM, K. (1977). Use of adenosine 5 -triphosphate as an indicator of the microbiota biomass in rumen contents. Applied and Environmental Microbiology 33, 528-537.

Fulghum, R. S. \& MOORE, W. E. C. (1963). Isolation, enumeration and characteristics of proteolytic ruminal bacteria. Journal of Bacteriology 85, 808815.

Groleau, D. \& Forsberg, C. W. (1981). Cellulolytic activity of the rumen bacterium Bacteroides succinogenes. Canadian Journal of Microbiology 27, 517530.

Hazlewood, G. P. \& Edwards, R. (1981). Proteolytic activities of a rumen bacterium, Bacteroides ruminicola R8/4. Journal of General Microbiology 125, 1115.

Hazlewood, G. P. \& Nugent, J. H. A. (1978). Leaf fraction 1 protein as a nitrogen source for the growth of a proteolytic rumen bacterium. Journal of General Microbiology 106, 369-371.

Hazlewood, G. P., Jones, G. A. \& Mangan, J. L. (1981). Hydrolysis of leaf fraction 1 protein by the proteolytic rumen bacterium Bacteroides ruminicola R8/4. Journal of General Microbiology 123, 223-232.

Hazlewood, G. P., Orpin, C. G., Greenwood, Y. \& BLACK, M. E. (1983). Isolation of proteolytic rumen bacteria by use of selective medium containing leaf fraction 1 protein (ribulosebisphosphate carboxylase). Applied and Environmental Microbiology 45, 1780-1784.

Hobson, P. N. (1969). Rumen bacteria. Methods in Microbiology 3B, 133-149.

holdeman, L. V., Cato, E. P. \& Moore, W. E. C. (eds). (1977). Anuerobic Laboratory Manual, 4th edn. Blacksburg, Virginia: V.P.I. Anaerobe Laboratory.

Holz, G. \& Bergmeyer, H. U. (1974). Acetate determination with acetate kinase and hydroxylamine. In Methods of Enzymatic Analysis, 2nd edn, vol. 3, pp. 1528-1532. Edited by H. U. Bergmeyer. London: Academic Press.

Hungate, R. E. (1966). The Rumen and Its Microbes. New York: Academic Press.

Hungate, R. E. (1969). A roll tube method for cultivation of strict anaerobes. Methods in Microbiology 3B, 117-132.
Kopecny, J. \& Wallace, R. J. (1982). Cellular location and some properties of proteolytic enzymes of rumen bacteria. Applied and Entironmental Microbiology 43, 1026-1033.

Marounek, M. \& Wallace, R. J. (1984). Influence of culture $E_{\mathrm{h}}$ on the growth and metabolism of the rumen bacteria Selenomonas ruminantium, Bacteroides amylophilus, Bacteroides succinogenes and Streptococcus botis in batch culture. Journal of General Microbiology 130, 223-229.

NoRTH, M. J. (1982). Comparative biochemistry of the proteinases of eucaryotic microorganisms. Microbiological Rerien's 46, 308-340.

Russell, J. B., Bottje, W. G. \& Cotta, M. A. (1981). Degradation of protein by mixed cultures of rumen bacteria: identification of Streptococcus bovis as an actively proteolytic rumen bacterium. Journal of Animal Science 53, 242-252.

SCOTT, H. W. \& Dehority, B. A. (1965). Vitamin requirements of several cellulolytic rumen bacteria. Journal of Bacteriology 89, 1169-1175.

Shane, B. S., Gouws, L. \& Kistner, A. (1969). Cellulolytic bacteria occurring in the rumen of sheep conditioned to low-protein teff hay. Journal of General Microbiology 55, 445-457.

Siddons, R. C. \& Paradine, J. (1981). Effect of diet on protein degrading activity in the sheep rumen. Journal of the Science of Food and Agriculture 32, 973 981.

Starr, M. P., Stolp, H., Truper, H. G., Balows, A. \& SCHLegel, H. G. (eds). (1981). The Prokaryotes, $a$ Handbook on Habitats, Isolation, and Identification of Bacteria, vol. II. New York: Springer-Verlag.

Stewart, C. S., Paniagua, C., Dinsdale, D., Cheng, K.-J. \& GarRow, S. H. (1981). Selective isolation and characteristics of Bacteroides succinogenes from the rumen of a cow. Applied and Environmental Microbiology 41, 504-510.

TEATHER, R. M. (1982). Maintenance of laboratory strains of obligately anaerobic rumen bacteria. Applied and Environmental Microbiology 44, 499-501.

VAREL, V. H., BRYANT, M. P., Holdeman, L. V. \& MOORE, W. E. C. (1974). Isolation of ureolytic Peptostreptococcus productus from feces using defined medium; failure of common urease tests. Applied Microbiology 28, 594-599.

W ALLACE, R. J. (1978). Control of lactate production by Selenomonas ruminantium : homotropic activation of lactate dehydrogenase by pyruvate. Journal of General Microbiology 107, 45-52.

WallaCE, R. J. (1979). Effect of ammonia concentration on the composition, hydrolytic activity and nitrogen metabolism of the microbial flora of the rumen. Journal of Applied Bacteriology 47, 443-455.

Wallace, R. J. (1983). Hydrolysis of $1+$ C-labelled proteins by rumen micro-organisms and by proteolytic enzymes prepared from rumen bacteria. British Journal of Nutrition 50, 345-355.

Wallace, R. J., Cheng, K.-J., Dinsdale, D. \& ØRSKOV, E. R. (1979). An independent microbial flora of the epithelium and its role in the ecomicrobiology of the rumen. Nature, London 279, 424-426.

Yuruwitz, E. C., Ghalambor, M. A. \& Heath, E. C. (1971). The structure of Aerobacter aerogenes capsular polysaccharide. Journal of Biological Chemistry 246, 5596-5606. 